Jurnal Indonesia Sosial Teknologi: p-ISSN: 2723 - 6609

e-ISSN : 2548-1398

Vol. 1, No. 4 November 2020

\title{
PERANCANGAN SISTEM INFORMASI PENGGAJIAN BERBASIS WEB PADA CV. ALONA JAYA
}

\author{
Andronias Siregar \\ Universitas Bina Sarana Informatika \\ Email: andronias.aoe@bsi.ac.id
}

\section{Abstract}

The function of a payroll application program is very important to support the smooth payment of employee salaries, therefore to meet the information needs of all parties who need it and to prioritize convenience in providing information services quickly and accurately, it is necessary to have a computerized data processing system. It is concluded that the employee payroll procedures used by $C V$. Basically Alona Jaya has not been well computerized, so data processing will be even more complicated if the process is done without using a payroll application program as a tool, because in data input and report preparation, accuracy and accuracy is required, because incoming data can be increased or changed during -time. Therefore, it is necessary to make software by adopting digital data processing, both in data input and in making reports in order to advance a service to company employees. The research method used is observational method, interview and literature study. The results of this study indicate that the computerized data processing tends to be younger and the results of data processing have a better level of accuracy than using manually. So from this research will be built a payroll information system using the programming language PHP and MySQL database to help work in performing employee payroll.

Keywords: Information Systems, Payroll, Employees

\begin{abstract}
Abstrak
Fungsi sebuah program aplikasi penggajian sangatlah penting untuk menunjang kelancaran pembayaran gaji karyawan, oleh karena itu untuk memenuhi kebutuhan informasi kepada semua pihak yang membutuhkan serta demi mengutamakan kemudahan dalam pelayanan informasi secara cepat dan akurat, maka diperlukan adanya suatu sistem pengolahan data yang terkomputerisasi. Disimpulkan bahwa prosedur penggajian karyawan yang dipakai oleh CV. Alona Jaya pada dasarnya belum terkomputerisasi dengan baik, sehingga pengolahan data akan semakin rumit apabila dalam pengerjaannya tanpa menggunakan suatu program aplikasi penggajian sebagai alat bantu, karena dalam penginputan data dan penyusunan laporan diperlukan ketelitian dan keakuratan, karena data yang masuk dapat bertambah dan atau berubah sewaktu-waktu. Oleh karena itu, perlu dibuat suatu perangkat lunak dengan mengadopsi pengolahan data digital, baik dalam penginputan data maupun dalam pembuatan laporan guna memajukan sebuah layanan kepada karyawan perusahaan. Metode penelitian yang digunakan adalah metode observari, interview dan studi pustaka. Hasil penelitian ini menunjukan
\end{abstract}


bahwa proses pengolahan data secara terkomputerisasi cenderung lebih muda dan hasil dari pengolahan data mempunyai tingkat keakuratan yang lebih baik dari pada menggunakan secara manual. Maka dari penelitian ini akan dibangun sebuah sistem informasi penggajian menggunakan bahasa pemrogramman PHP dan database MySQL untuk membantu pekerjaan dalam melakukan penggajian karyawan.

Kata kunci: Sistem Informasi, Penggajian, Karyawan

\section{Pendahuluan}

Perkembangan teknologi komputer pada saat sekarang ini mempunyai peranan yang sangat penting dalam kehidupan masyarakat. Penerapan teknologi informasi memberikan kemudahan instansi atau lembaga khususnya dalam melaksanakan kegiatan dan salah satunya adalah digunakan sebagai manajemen data pegawai, manajemen data absensi, manajemen data penggajian (Rachmaniar, 2019). Karyawan merupakan penggerak utama salah satu kebijakan perusahaan yang memberikan sumbangan pemikiran tenaga dan keahlian (Munthe, Silalahi, \& Simamora, 2017).

Proses penggajian secara sering mengalami permasalahan-permasalahan seperti data yang diinput tidak akurat, hilangnya data-data dikarenakan tidak adanya tempat penyimpanan yang aman, penumpukan data-data, data laporan yang kurang detail, sering terjadi kesalahan dalam penjumlahan (Yulistyanti, 2020).

Pengelolaan proses penggajian pada CV Alona Jaya masih menggunakan Microsoft Excel, Menurut (Lasimin, Haq, \& Verry, 2020) pengelolaan menggunakan Microsoft Excel dianggap tidak efektif dan tidak efisien, menghambat kinerja perusahaan khususnya dalam hal pengelolaan gaji karyawan.

Menurut (Oktavia, Sadikin, \& Irawan, 2019) mengatakan sama menggunakan bantuan microsoft excel yang menyebabkan perhitungan gaji yang lambat dan kurang akurat dikarenakan banyaknya karyawan yang bekerja, pencatatan data absensi karyawan masih menggunakan lembaran absensi sehingga dapat menimbulkan kecurangan dalam pencatatan kehadiran karyawan dan sulit mendapatkan keakuratan data kehadiran karyawan untuk melakukan tindak denda keterlambatan karyawan akibatnya proses perhitungan penggajian karyawan membutuhkan waktu yang lama dalam melakukan rekap laporan gaji bulanan karyawan.

Sistem penggajian adalah sistem informasi yang menyediakan informasi bagaimana suatu siklus penggajian yang ada dalam suatu perusahaan diatur dan berjalan sesuai dengan kebijakan masing-masing perusahaan (Syamsiyati, W, \& S, 2019). Sehingga tidak mengherankan bahwa kadang perusahaan khususnya bagian keuangan mendapati kesulitan dalam melakukan perhitungan gaji. Mengingat masalah gaji adalah masalah yang sensitif, untuk mengatasi masalah-masalah tersebut maka perusahaan perlu mengevaluasi sistem penggajian (Syamsiyati et al., 2019).

Pemberian gaji yang cukup dan memadai akan membawa pengaruh positif terhadap semangat kerja karyawan. (Widiastutik, Probowulan, \& Puspito, 2020). Dengan pengolahan data yang baik yang diolah sedemikian rupa senantiasa dapat mengatasi masalah yang terjadi dan dapat menghasilkan informasi yang cepat, tepat dan akurat (Suripatty, 2020).

Merancang sebuah sistem penggajian dalam bentuk aplikasi sebagai solusi baik bagi sistem yang efektif dan efisien (Widodo \& Triandi, 2019). Diharapkan pembuatan sistem informasi penggajian pada CV. Alona Jaya dapat mempermudah dan mengakuratkan proses perhitungan gaji pokok, lembur dan pembuatan laporan. 


\section{Metode Penelitian}

Untuk memperoleh data dalam pengembangan sistem informasi penggajian teknik yang digunakan dalam pengumpulan data (Sianturi \& Wijoyo, 2020):

1. Metode pengamatan langsung (Observasi)

Mengumpulkan data dengan melakukan pengamatan secara langsung kegiatan pengolahan data guna mengetahui masalah yang sering terjadi.

2. Metode wawancara (Interview)

Pengumpulan data secara tatap muka langsung dengan orang yang diwawacarai untuk diminta datanya. Disini penulis mengajukan pertanyaan langsung kepada owner untuk mengatahui system penggajian.

3. Metode studi pustaka (Literatur)

Teknik yang dilakukan dengan cara membaca buku-buku yang berhubungan dengan sistem penggajian dan perancangan program yang digunakan sebagai referensi.

Sedangkan dalam pengembangan perangkat lunak, metode yang digunakan dalam pengembangan perangkat lunak adalah menggunakan model Waterfall. Adapun tahaptahap pengembangan model Waterfall yang digunakan untuk membangun sistem ini adalah sebagai berikut (Masturoh, Wijayanti, \& Prasetyo, 2019):

a. System / Information Engineering and Modeling

Permodelan ini diawali dengan mencari kebutuhan dari keseluruhan sistem yang akan diaplikasikan ke dalam bentuk software. Hal ini sangat penting, mengingat software harus dapat berinteraksi dengan elemen-elemen yang lain seperti hardware, database. Tahap ini sering disebut dengan Project Definition.

b. Software

Requirements Analysis Proses pencarian kebutuhan diintensifkan dan difokuskan pada software. Untuk mengetahui sifat dari program yang akan dibuat, maka para software engineer harus mengerti tentang domain informasi dari software, misalnya fungsi yang dibutuhkan, user interface.

c. Design

Proses ini digunakan untuk mengubah kebutuhan-kebutuhan diatas menjadi representasi ke dalam bentuk "blueprint" software sebelum coding dimulai. Desain harus dapat mengimplementasikan kebutuhan yang telah disebutkan pada tahap sebelumnya.

d. Coding

Untuk dapat dimengerti oleh mesin, dalam hal ini adalah komputer, maka desain tadi harus diubah bentuknya menjadi bentuk yang dapat dimengerti oleh mesin, yaitu ke dalam bahasa pemrograman melalui proses coding. Tahap ini merupakan implementasi dari tahap design yang secara teknis nantinya dikerjakan oleh programmer.

e. Testing / Verification

Sesuatu yang dibuat haruslah diujicobakan. Demikian juga dengan software. Semua fungsi-fungsi software harus diujicobakan, agar software bebas dari error, dan hasilnya harus benar-benar sesuai dengan kebutuhan yang sudah didefinisikan sebelumnya.

f. Maintenance

Pemeliharaan suatu software diperlukan, termasuk di dalamnya adalah pengembangan, karena software yang dibuat tidak selamanya hanya seperti itu. 
Ketika dijalankan mungkin saja masih ada error kecil yang tidak ditemukan sebelumnya, atau ada penambahan fitur-fitur yang belum ada pada software tersebut. Pengembangan diperlukan ketika adanya perubahan dari eksternal seperti ketika ada pergantian sistem operasi, atau perangkat lainnya.

\section{Hasil dan Pembahasan}

Diagram yang dibuat menggunakan UML

A. Use Case Diagram Mengelola Data Penggajian

Use case diagram adalah diagram yang mengambarkan kebutuhan sistem dari sudut pandang user, yang memperlihatkan hubungan-hubungan yang terjadi antara actor dengan use case dalam sistem. Berikut ini adalah use case yang berjalan pada sistem bagian keuangan, dimana bagian keuangan dapat mengelola data penggajian, baik dalam mencari data, melakukan penginputan data, mengubah data, dan menyimpan data.

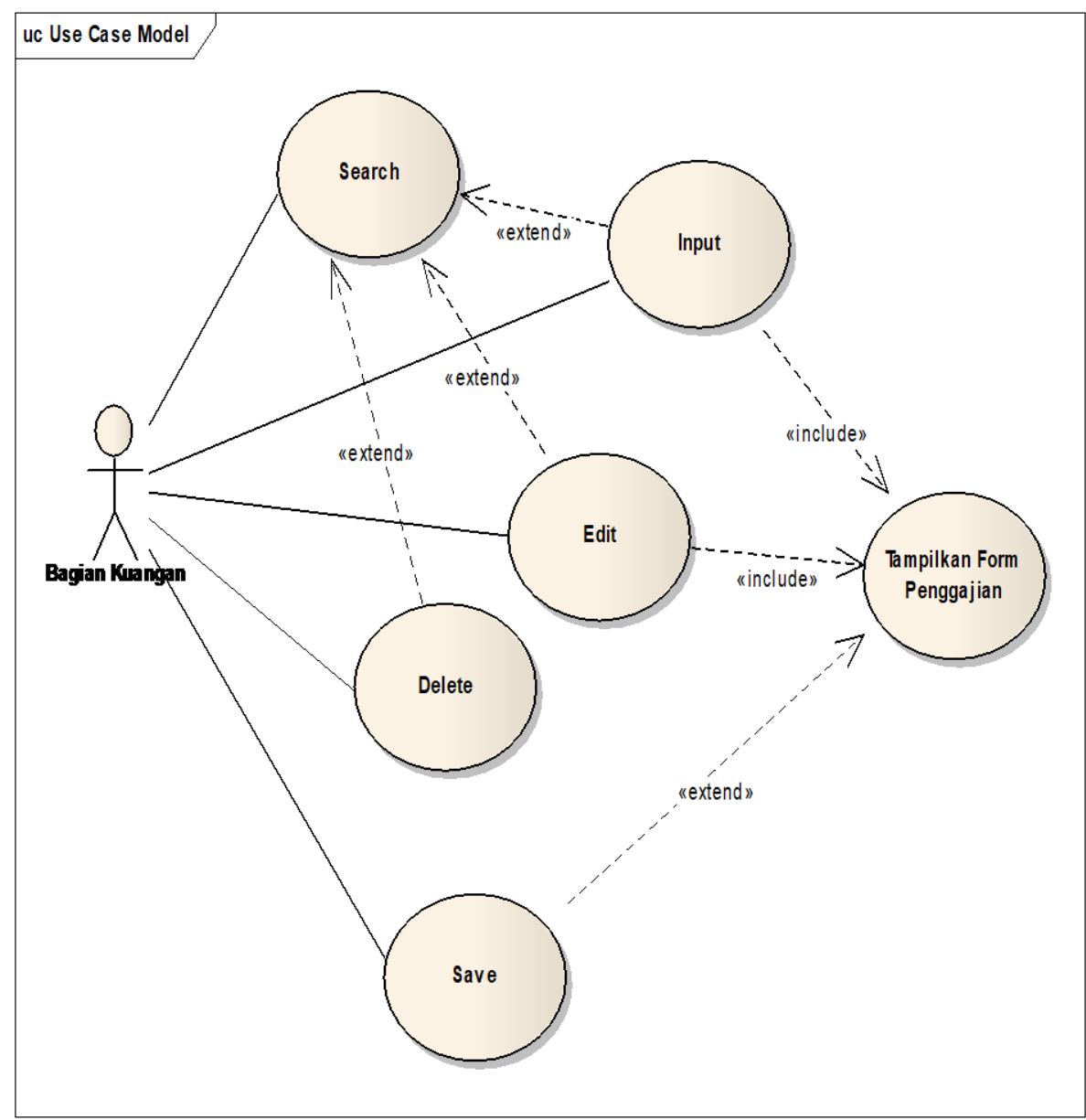

Gambar 1. Use Case Diagram Mengelola Data Penggajian

Tabel 1. Use Case Diagram Mengelola Data Penggajian

\begin{tabular}{|l|l|}
\hline Use Case Name & Mengelola Data Penggajian \\
\hline Requirements & B7 \\
\hline Goal & $\begin{array}{l}\text { Bagian keuangan menghitung gaji } \\
\text { karyawan }\end{array}$ \\
\hline Pre-conditions & Bagian keuangan telah login \\
\hline
\end{tabular}


Perancangan Sistem Informasi Penggajian Berbasis Web Pada CV. Alona Jaya

\begin{tabular}{|l|l|}
\hline Post-conditions & Data bagian tersimpan \\
\hline Failed end contitions & $\begin{array}{l}\text { Gagal melakukan penyimpanan / } \\
\text { perubahan / penghapusan data } \\
\text { penggajian }\end{array}$ \\
\hline Primary Actor & Bagian keuangan \\
\hline Main Flow / Basic & $\begin{array}{l}\text { 1. Bagian keuangan memilih nik } \\
\text { karyawan } \\
\text { 2.Bagian keuangan menginput } \\
\text { data absensi karyawan } \\
\text { 3.Bagian keuangan menyimpan } \\
\text { gaji karyawan }\end{array}$ \\
\hline Alternated / Invariant & $\begin{array}{l}\text { Bagian keuangan merubah data } \\
\text { penggajian, jika ada kesalahan } \\
\text { dalam proses penggajian karyawan }\end{array}$ \\
\hline
\end{tabular}

B. Diagram Activity Bagian Keuangan

Menggambarkan alir aktifitas dalam sebuah sistem yang sedang dalam proses perancangan, tepatnya bagaimana awal alir aktifitas, Keputasan atau decision yang mungkin ada dan bagaimana alir aktifitas berakhir. Activity Diagram merupakan state diagram khusus, dimana sebagian besar state adalah sebuah action dan sebagian besar transisi di-trigger oleh selesainya state sebelumnya (Sastra, Musyaffa, \& Supriadi, 2019).

Berikut ini adalah alur aktifitas dalam sistem yang dirancang, bagaimana alur aktifitas dari sistem bagian keuangan yang berjalan. 


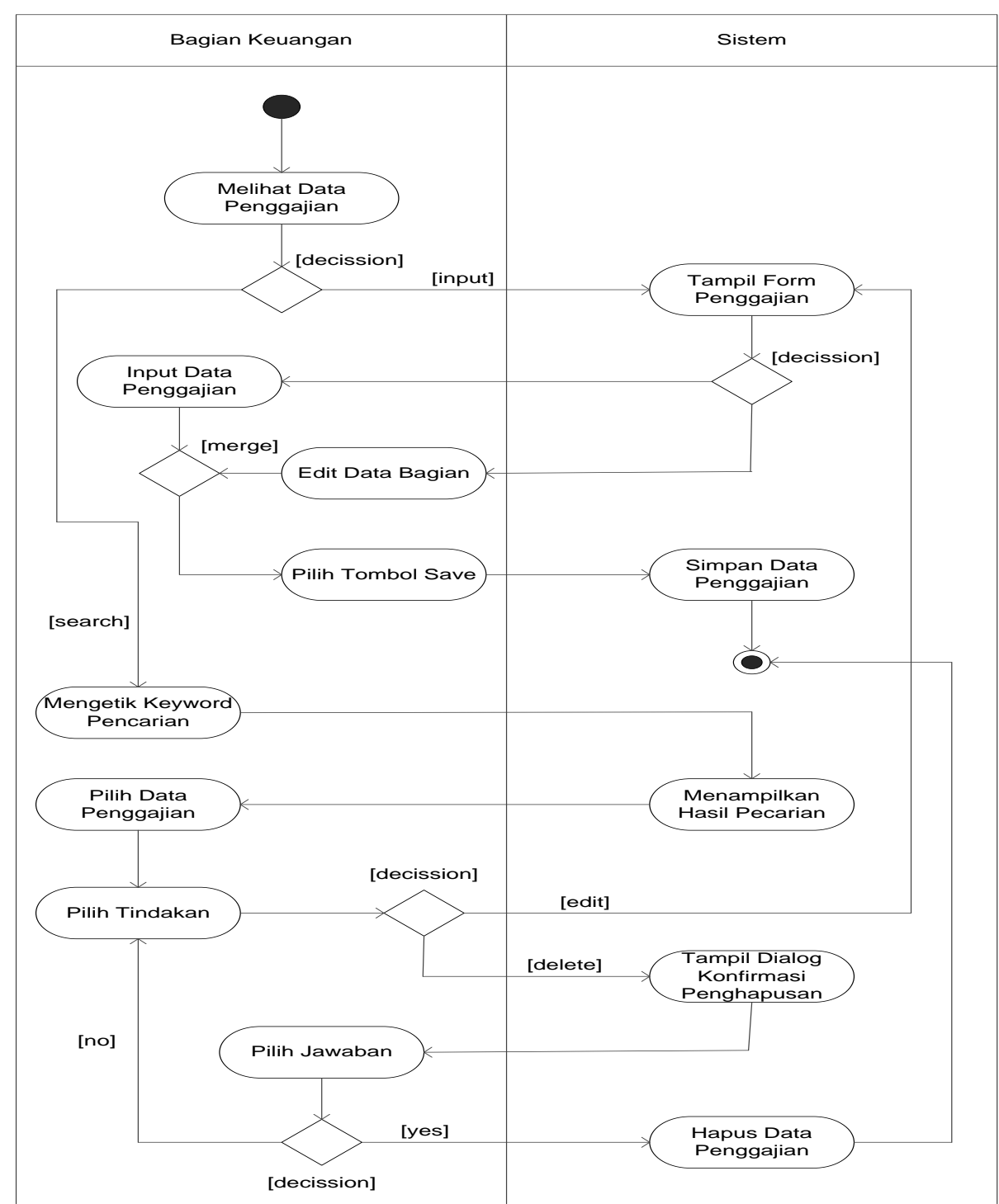

Gambar 2. Activity Diagram Mengelola Data Penggajian

Perancangan basis data menghasilkan pemetaan tabel-tabel yang digambarkan dengan Entity Relationship Diagram (ERD) dan Logical Relational Structure (LRS).

\section{a. Entity Relationship Diagram (ERD)}

ERD merupakan salah satu cara untuk mengolah database sehingga data tersebut dapat diketahui hubungan antara file dan teknik ini dapat digunakan untuk mengatasi terjadinya redundasi data atau sejenisnya dan bentuk entity relationship (Saidah \& Syarifuddin, 2020). Pada Entity Relationship Diagram menggambarkan hubungan antar entitas yang direlasikan dengan atribut kunci pada masing-masing entitas. Berikut ini adalah ERD pada sistem informasi penggajian pada CV. Alona Jaya 


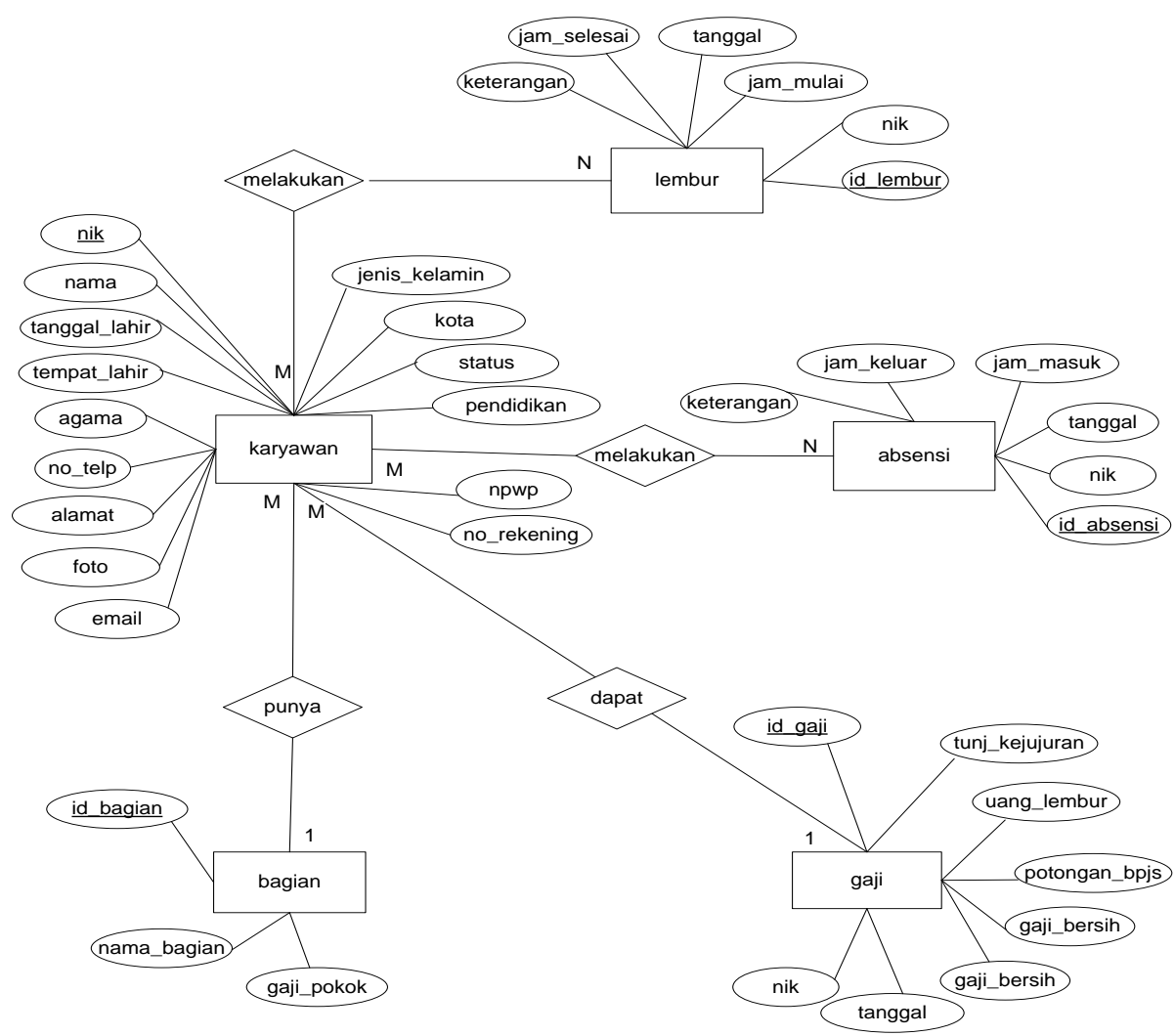

Gambar 3. Entity Relationship Diagram (ERD)

b. Logical Relational Structure (LRS)

Menurut (Sari, Wahyuni, \& Narti, 2019) Logical Record Structure (LRS) digambarkan dengan kotak persegi panjang dan dengan nama yang unik. File record pada LRS ditempatkan dalam kotak.

LRS didapat dari pengolahan ERD, dimana terdapat lima entitas yang dipakai ERD kemudian di transformasikan ke dalam bentuk tabel maka didapat lima tabel yang akan digunakan dalam membangun sistem informasi penggajian yaitu tabel karyawan, tabel absensi, tabel lembur, tabel gaji, dan tabel bagian. Kemudian atribut akan di transformasikan menjadi field untuk membangun tabel, sedangkan tiap relasi antar tabel tetap sama dengan ERD. Berikut adalah gambar LRS yang sudah di transformasikan dari ERD. 
Andronias Siregar

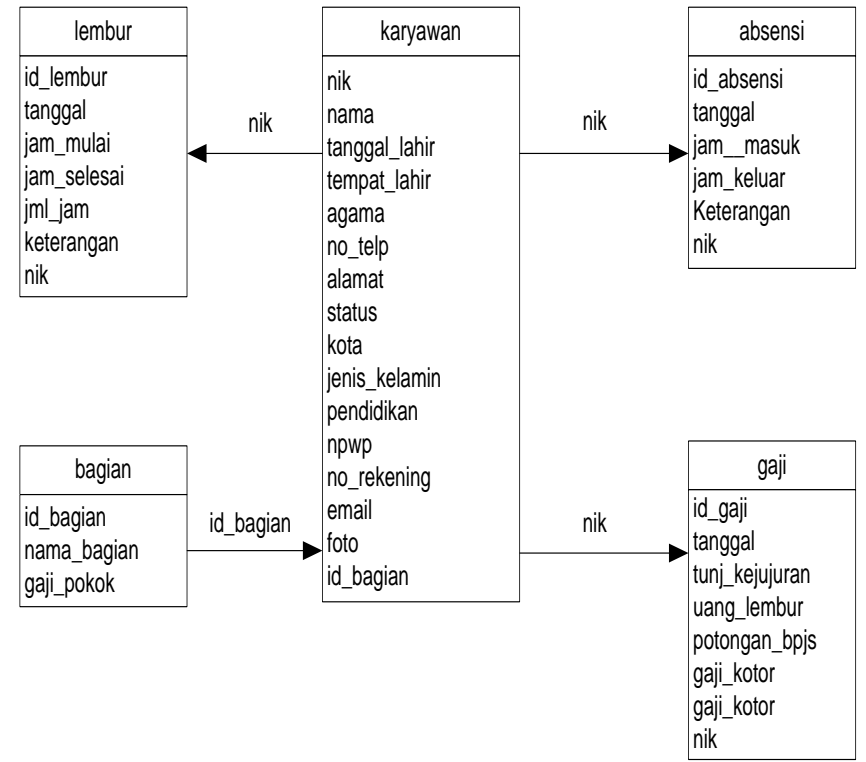

Gambar 4. Logical Relational Structure (LRS)

Adapun tampilan-tampilan dari program penggajian pada CV. Alona Jaya dari sistem usulan sebagai berikut ini:

A. Form Login

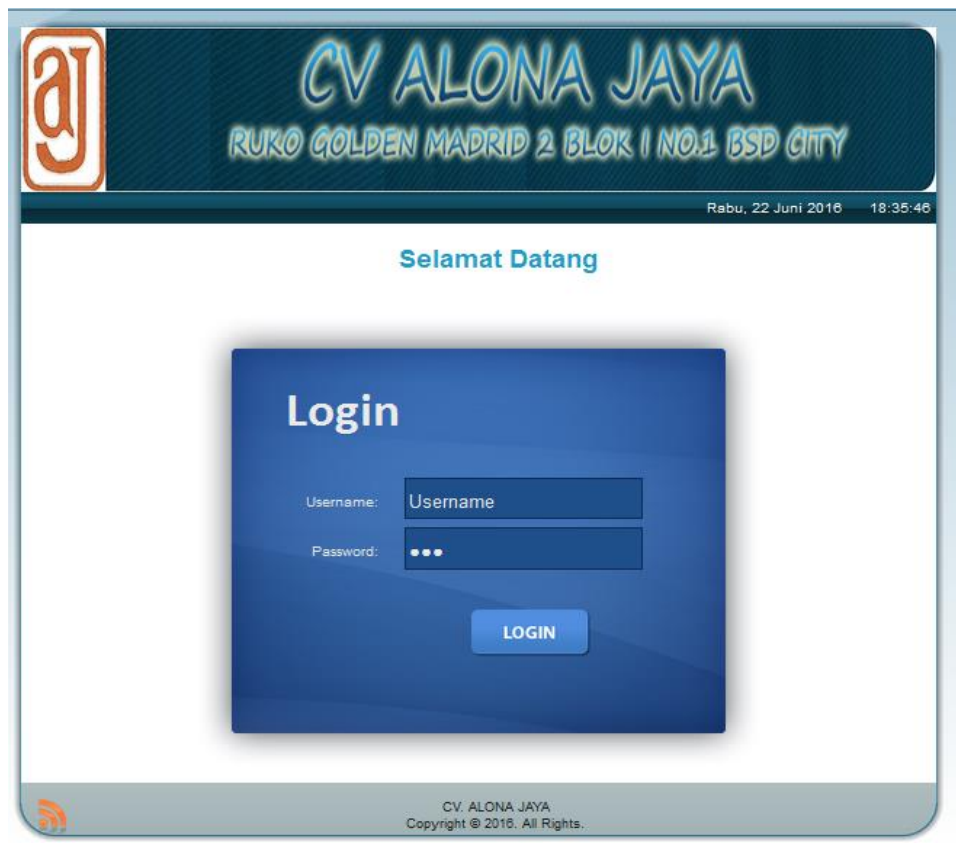

Gambar 5. Form Login Administrator

Pada Gambar 5. Ini merupakan tampilan dari form login untuk masuk ke halaman administrator 
B. Form Input Data Karyawan

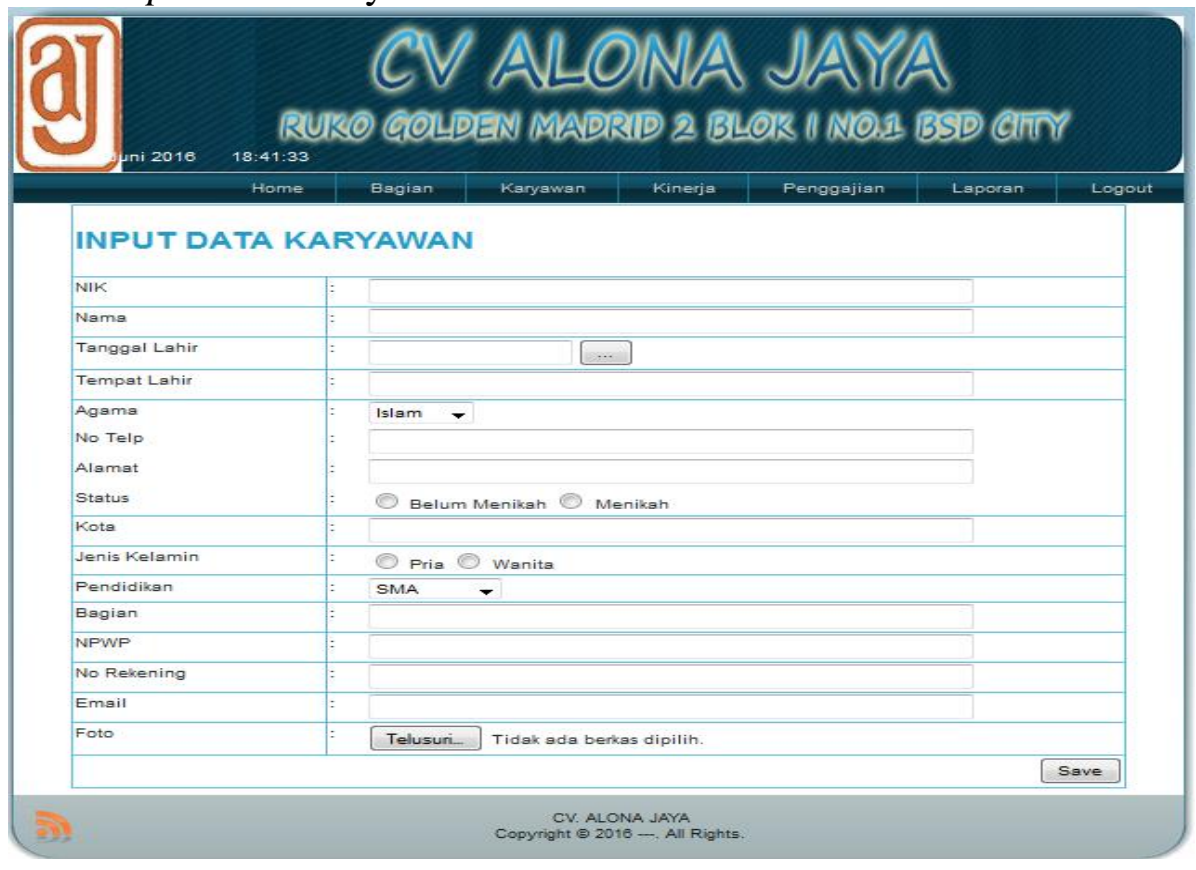

Gambar 6. Input Data Karyawan

Pada Gambar 6. Merupakan tampilan administrator untuk menginput data karyawan baru atau mengubah data karyawan.

C. Form Input Data Absensi

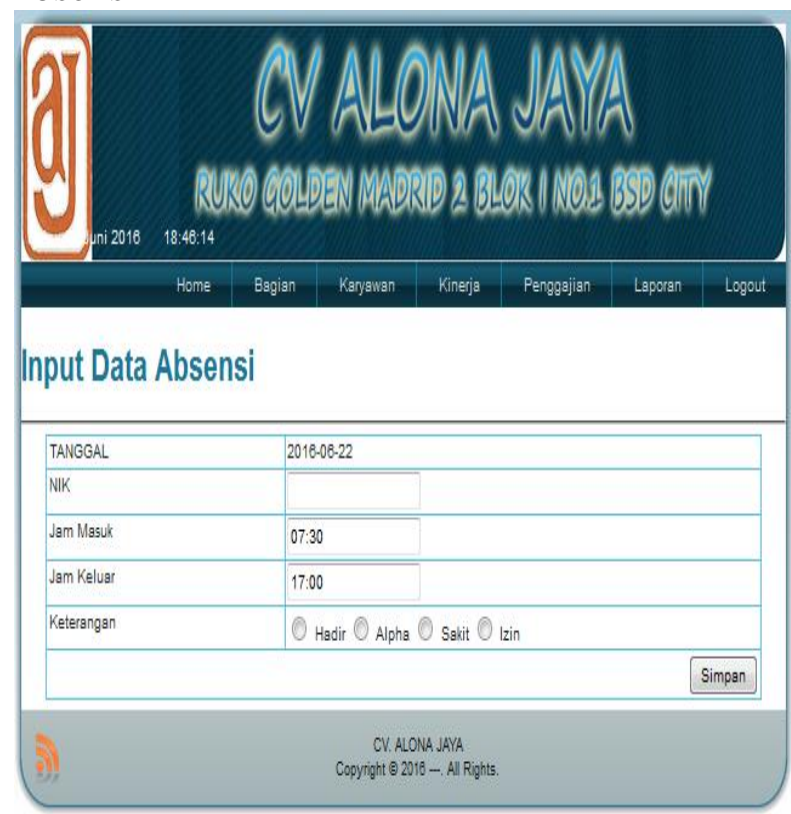

Gambar 7. Input Data Absensi

Pada Gambar 7. Merupakan tampilan administrator untuk menginput data absensi karyawan. 
D. Form Input Data Gaji Karyawan

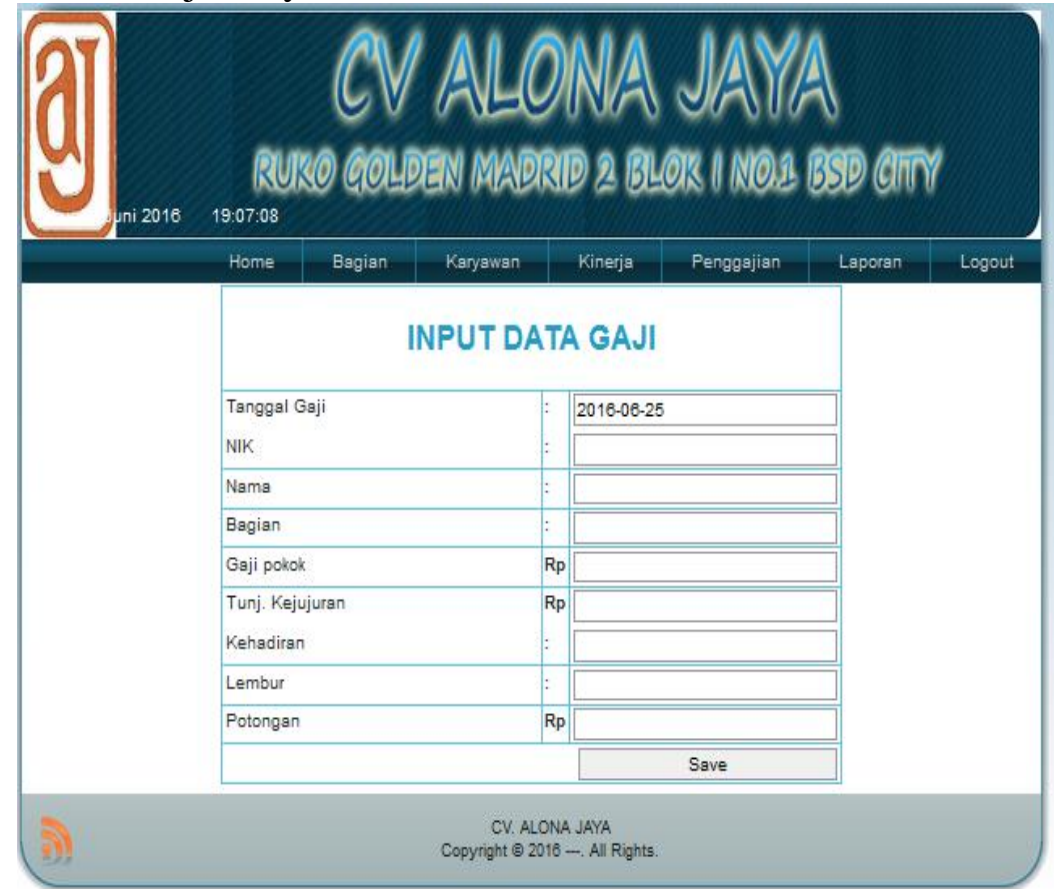

Gambar 8. Tambah Data Penarikan

Pada Gambar 8. Merupakan tampilan dari administrator untuk menginput transaksi penggajian karyawan.

\section{Kesimpulan}

Sistem pengolahan data pada CV. Alona Jaya masih bersifat manual sehingga akan banyak kendala-kendala yang akan ditemui seperti kerangkapan data, data hilang, lambannya penggajian akibat dari pencatatan yang masih manual, kesulitan mencari data dan ketidak tepatan waktu dalam pembuatan laporan.

Dengan dibuatkannya software pengolahan data penggajian karyawan akan meningkatkan kualitas pelayanan terhadap karyawannya, karena akan menghemat waktu saat pemprosesan data. Selain itu juga dapat menghasilkan laporan yang akurat, relevan dan tepat waktu.

Dalam perancangan sistem informasi penggajian ini, penulis merancang program yang akan meminimalisir kesalahan-kesalahan yang terjadi serta mempermudah dalam pengolahan data penggajian yang terdiri dari file data karyawan, file data bagian, file data absensi dan file data gaji. Program ini juga akan meningkatkan kualitas kinerja khususnya di bagian keuangan instansi Dinas Kesehatan. Kemudahan lain yang didapatkan adalah laporan data karyawan, laporan data gaji dan slip gaji.

Dengan adanya program pengolahan data penggajian karyawan ini maka akan didapatkan kemudahan dalam pengimputan data, dan penyimpanan data serta akan didapatkan output yang akurat dan sesuai dengan kebutuhan. Hal ini nantinya akan lebih meningkatkan kinerja di bagian keuangan. 


\section{Bibliografi}

Lasimin, Haq, A., \& Verry. (2020). Sistem Informasi Penggajian PT . Kalisha Utama Ghani Cilacap Menggunakan Framework Laravel, 4(2), 153-162.

Masturoh, S., Wijayanti, D., \& Prasetyo, A. (2019). Sistem Informasi Akademik Berbasis Web Menggunakan Model Waterfall Pada SMK ITENAS Karawang, 6(1), 62-68.

Munthe, A. B., Silalahi, M., \& Simamora, R. J. (2017). FUNGSI SISTEM INFORMASI AKUNTANSI PENGGAJIAN DALAM MENUNJANG EFEKTIVITAS PENGENDALIAN INTERNAL PENGGAJIAN PADA PTPN III (PERSERO) MEDAN. METHOMIKA: Jurnal Manajemen Informatika \& Komputerisasi Akuntansi, 1(1), 46-57.

Murti, N. W., Wiliandi, D., Saputra, R. D., Haryono, W., Informatika, T., Pamulang, U., ... Pamulang, K. (2020). Pengembangan Sistem Informasi Manajer Suku Cadang Sepeda Motor Berbasis Web di Bengkel Benny Motor, 1(3), 100-106.

Oktavia, F., Sadikin, A., \& Irawan, B. (2019). PERANCANGAN SISTEM INFORMASI PENGGAJIAN KARYAWAN PADA PT . SAWMILL JAMBI, $1(4), 265-277$.

Rachmaniar, A. (2019). Sistem Informasi Penggajian Dosen Kampus STMIK Jakarta STI \& K Menggunakan PHP dan MySQL, 18, 1-8.

Saidah, N., \& Syarifuddin. (2020). Implementasi Sistem Informasi Rekam Medis pada Klinik Jejaring Padjadjaran Basmallah Garut, (2), 51-56.

Sari, E. P., Wahyuni, A., \& Narti. (2019). Sistem Informasi Sekolah Berbasis Web, 5(1), 87-94.

Sastra, R., Musyaffa, N., \& Supriadi, B. (2019). Perancangan sistem informasi penggajian menggunakan model waterfall pada pt. medina. JTIULM, 4(2), 71-78.

Sianturi, K., \& Wijoyo, H. (2020). Rancang Bangun System Informasi Penggajian Dan Absensi Karyawan Megara Hotel Pekanbaru Berbasis Web, 2(2), 65-76.

Suripatty, H. . (2020). Sistem informasi penggajian pada kantor dinas pendidikan dan pengajaran kabupaten nabire, 5(1), 14-21.

Syamsiyati, W, E. M., \& S, Y. C. (2019). Evaluasi Penerapan Sistem Penggajian pada Tsabita Halal Boga, 19(2).

Widiastutik, V., Probowulan, D., \& Puspito, A. (2020). PERANCANGAN SISTEM INFORMASI AKUNTANSI PENGGAJIAN (MANUAL), 2, 335-345.

Widodo, \& Triandi, D. (2019). Merancang sistem informasi penggajian karyawan pada 
Andronias Siregar

bank bpr sunni kotaraja jayapura, 1(12), 11-16.

Yulistyanti, D. (2020). Perancangan Aplikasi Penggajian Karyawan pada SMP Islam Taman Quraniyah Berbasis JAVA, 9(2), 79-90. 